\title{
Evaluation of Nickel Release in Blood and Periodontal Tissue with the Use of NiTi Wires, Bands and Brackets in Orthodontics - A Systematic Review
}

\author{
Shreya Kishore ${ }^{1}$, A. Sumathi Felicita², Suvetha Siva ${ }^{3}$ \\ 1,3 Department of Orthodontics, SRM Dental College, Ramapuram, Chennai, Tamil Nadu, India. \\ ${ }^{2}$ Department of Orthodontics, Saveetha Dental College, Poonamalle, Chennai, Tamil Nadu, India.
}

\section{ABSTRACT}

\section{BACKGROUND}

It is of outmost importance to know the effects of nickel on a cellular level. The objective of this systematic review was to analyse the factors affecting nickel release, the amount of nickel being released in commercially available NiTi wires and to also analyse the blood / periodontal evaluation after orthodontic treatment in conventional and nickel free brackets.

\section{METHODS}

For this systematic review, relevant articles were searched in PubMed, MedLine, Cochrane, EMBASE and Google Scholar databases, along with a complimentary manual search of all orthodontic journals from January 1980 till the year 2019 December. The study included in vitro and in vivo studies. 14 articles were included in this systematic review.

\section{RESULTS}

160 articles were obtained initially. 41 were obtained by a manual search. 186 articles were excluded based on the inclusion criteria and 14 articles were found to be eligible.

\section{CONCLUSION}

This systematic review shows that nickel solution at a minimal concentration could damage human gingival fibroblast. As the carcinogenic effect of nickel has been already confirmed, other alloys that do not contain the heavy metal nickel can be used or standardization of the amount of nickel leach out from the appliance should be considered.

\section{KEY WORDS}

NiTi, Nickel Release, Periodontal Tissue or Periodontium, Cytotoxicity, Orthodontics
Corresponding Author:

Dr. Shreya Kishore,

Senior Lecturer,

Department of Orthodontics,

SRM Dental College, Barathi Salai,

Ramapuram, Chennai - 600089,

Tamil Nadu, India.

E-mail:dr.shreyakishore@gmail.com

DOI: $10.14260 /$ jemds/2021/321

How to Cite This Article:

Kishore S, Felicita AS, Siva S. Evaluation of nickel release in blood and periodontal tissue with the use of NiTi wires, bands and brackets in orthodontics - a systematic review. J Evolution Med Dent Sci 2021;10(20):1539-1546, DOI: $10.14260 /$ jemds $/ 2021 / 321$

Submission 08-01-2021,

Peer Review 17-03-2021,

Acceptance 23-03-2021,

Published 17-05-2021.

Copyright (C) 2021 Shreya Kishore et al. This is an open access article distributed under Creative Commons Attribution License [Attribution 4.0 International (CC BY 4.0)] 


\section{BACKGROUND}

Nickel was discovered by Axel Fredrik Crontedt in Sweden in 1751. It is from the German word "Kupernickel," meaning devils copper or St Nicholas Copper. Nickel [Ni] and chromium [Cr] containing alloys are present in a wide variety of appliances, auxiliaries, and utilities used in orthodontics and thus have become an integral part of routine orthodontic intervention. ${ }^{1}$ Nickel is the most common cause of metalinduced allergic content dermatitis in human beings and produces more allergic reaction than all other metals combined. Second in frequency is chromium. Various appliances like the maxillary expansion appliance, lingual arches stay in mouth for a very long period of time. A minimum of 13 months of appliance wear is considered necessary for visualizing effects. Lingual arches which are commonly used as space maintainers are given to the patient from a very young age of 6 years until $13-14$ years when the orthodontic treatment is completed. Hence it is utmost important to dwell upon the cellular effects. The oral cavity is a complete corrosion centre, with many factors that enhance the biodegradation of the orthodontic appliances. ${ }^{2-4}$ The conventional orthodontic appliances consist of orthodontic bands, brackets, and arch wires, which were introduced in 1930s. Since then the alloys have become an invaluable material in orthodontics, which are made of stainless steel containing 8-12\% nickel, 17-22\% chromium, and various proportions of manganese, copper, titanium, and iron. ${ }^{2}$ These are extremely durable and relatively inexpensive. The combination of the alloy materials is near each other, and in hostile conditions leading to corrosion and adverse reaction biologically and increases the friction mechanically. When using nickel titanium (NiTi) arch wire for dental orthodontic treatment, the possible danger associated with arch wire corrosion derives from the biologically harmful effects due to the released $\mathrm{Ni}$ ion.5,6 Therefore, NiTi arch wire with a good corrosion resistance is crucial to its biocompatibility. On the other hand, the surface corrosion of NiTi arch wires may increase the friction that appears at the interface between the arch wire and bracket, reducing the free sliding action during orthodontic treatment. Various in vitro and in vivo methods have been carried out to evaluate the release of metals and their contents in saliva and blood. From these studies, it is concluded that metal released from the conventional appliances in saliva and blood samples were well below the average dietary intake and did not reach the toxic concentrations. It should be kept in mind that we cannot exclude the fact that even non-toxic concentration might be enough to induce effects in cells of oral mucosa. 4,5 There have been many studies that were carried out to evaluate the nickel release. However, there is no standardization regarding the amount of nickel that can be leached as the carcinogenic effect of the nickel has been proved. The cause and effect of this on human have never been demonstrated except that few studies show that there is DNA damage in mucosa cells. Saliva acts as an electrolyte for electron and ion conduction, and the fluctuation of $\mathrm{pH}$ and temperature, enzymatic and microbial activity, and the various chemicals introduced into the oral cavity through food and drink as corrosion conductors. ${ }^{7-9}$ Factors affecting nickel release can be broadly classified as the following: $\mathrm{pH}$ of saliva, shape and dimension of wire, surface roughness and friction, galvanic corrosion within brackets and arch wires, time duration, based on manufacturers and products, and fluoride dentifrices from tooth pastes, while age and sex are not a prominent factor. ${ }^{10-18}$ Hence, the objective of this systematic review is to analyse the factors affecting nickel release, the amount of nickel being released in commercially available NiTi wires and to also analyse the blood / periodontal evaluation after orthodontic treatment in conventional and nickel free brackets.

\section{METHODS}

\section{Search Strategy}

The research question was "Nickel release in various commercially available Niti wires and brackets and the factors influencing its release." Databases included in the search: PubMed, MedLine, Cochrane, Google Scholar, Embase, Science Direct and a complimentary individual journal search.

A complimentary manual search was also done in various orthodontic journals that included World Journal of Orthodontics, American Journal of Orthodontics and Dentofacial Orthopaedics, European Journal of Orthodontics, Journal of Clinical orthodontics and Angle orthodontics. The articles included in this review were over a span of 24 years, from 1980 till 2019. The following mesh words and key words along with Boolean operators were used: nickel in nickel titanium wires) and ((blood and periodontal evaluation)J) or nickel in blood) and nickel titanium wires used in orthodontics) or fixed orthodontic therapy) or nickel titanium wires in fixed orthodontic therapy) and nickel release in blood) and nickel release in periodontium. The number of articles obtained are given in Table 1.

\begin{tabular}{|c|c|c|c|}
\hline Sl. No. & Database & Search terms & Articles found \\
\hline 1 & PubMed central (Advanced search) & $\begin{array}{l}((((((((\text { nickel) AND nickel in nickel titanium wires) AND ((blood and periodontal evaluation))) OR nickel in } \\
\text { blood) AND nickel titanium wires used in orthodontics) OR fixed orthodontic therapy) OR nickel titanium } \\
\text { wires in fixed orthodontic therapy) AND nickel release in blood) AND nickel release in periodontium }\end{array}$ & 41 \\
\hline 2 & MedLine & $\begin{array}{l}((((((((\text { nickel) AND nickel in nickel titanium wires) AND ((blood and periodontal evaluation))) OR nickel in } \\
\text { blood) AND nickel titanium wires used in orthodontics) OR fixed orthodontic therapy) OR nickel titanium } \\
\text { wires in fixed orthodontic therapy) AND nickel release in blood) AND nickel release in periodontium }\end{array}$ & 25 \\
\hline 3 & Cochrane & $\begin{array}{l}\text { (nickel in nickel titanium wires) AND (blood and periodontal evaluation) AND (nickel titanium wires used in } \\
\text { orthodontics) AND (nickel release in blood) AND (nickel release in periodontium) }\end{array}$ & 0 \\
\hline 4 & Google Scholar & $\begin{array}{l}((((((((\text { nickel) AND nickel in nickel titanium wires) AND ((blood and periodontal evaluation))) OR nickel in } \\
\text { blood) AND nickel titanium wires used in orthodontics) OR fixed orthodontic therapy) OR nickel titanium } \\
\text { wires in fixed orthodontic therapy) AND nickel release in blood) AND nickel release in periodontium }\end{array}$ & 61 \\
\hline 5 & EMBASE & $\begin{array}{l}\text { (nickel in nickel titanium wires) AND (blood and periodontal evaluation) AND (nickel titanium wires used in } \\
\text { orthodontics) AND (nickel release in blood) AND (nickel release in periodontium) }\end{array}$ & 0 \\
\hline 6 & Science Direct & $\begin{array}{l}\text { (nickel in nickel titanium wires) AND (blood and periodontal evaluation) AND (nickel titanium wires used in } \\
\text { orthodontics) AND (nickel release in blood) AND (nickel release in periodontium) }\end{array}$ & 33 \\
\hline 7 & Complimentary individual journal search & Evaluation of nickel release and blood and periodontal tissue with the use of NiTi wires in orthodontics & 41 \\
\hline \multicolumn{4}{|c|}{ Table 1. Search Database } \\
\hline
\end{tabular}




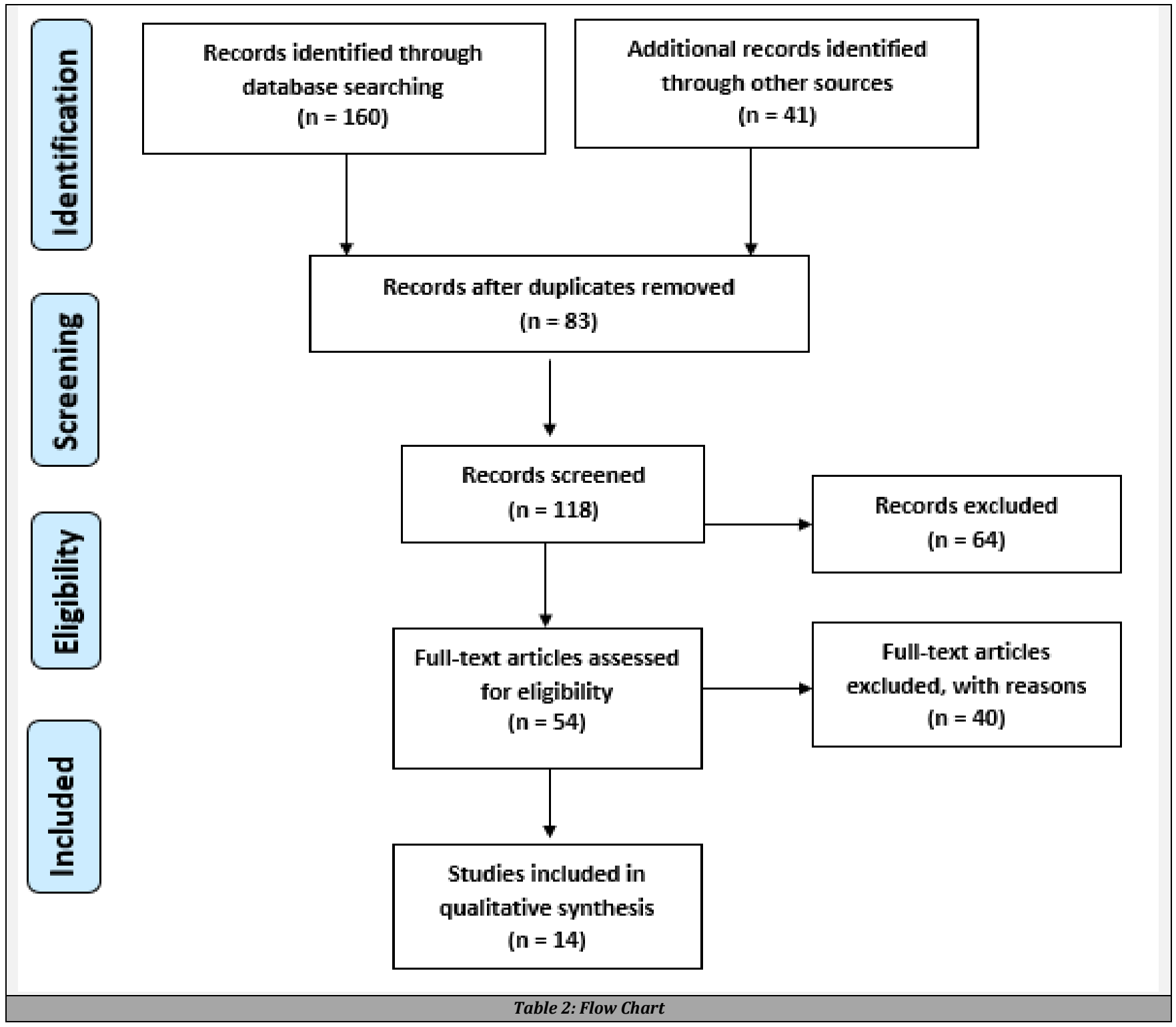

In vivo and in vitro articles, where studies on Niti wires were conducted, dated from 1980 till 2019 were included in the study. Articles that described the various amounts of nickel released from various wires used in orthodontic treatment were identified. Review articles and case reports were excluded. (Table 2)

\section{Data Extraction}

Data extraction was done by two reviewers. Studies that did not meet the inclusion criteria were not selected. Author, Year, Location, Type of Study, Participants (n), M / F (n), and Age (Years) Source of nickel (bracket / arch wire / band),

Characteristics of the attachment used such as slot/dimension of the arch wire etc, duration of time in the oral cavity, outcome, any other details from the article that can be recorded, was tabulated. (Table 3, 4 and 5) The articles selected were assessed for the risk of bias and were tabulated. This was done to check the quality of articles that were selected. (Table 6).

\section{RESULTS}

160 articles were obtained initially. 41 were obtained by a manual search. 186 articles were excluded based on its relevance to the search, case reports, reviews, short studies were also excluded. 14 articles were found to be eligible based on the selected criteria. The articles included were all in vitro studies. (Table 2, Table 3).

Factors Affecting Nickel Release - (Table 3)

Park \& Shearer also measured the release of nickel and chromium from the simulated orthodontic appliances by atomic absorption spectrophotometry in-vitro, and reported that the average release for nickel was $40 \mathrm{mic}$.gm/day. Nickel release depends on the $\mathrm{pH}$ of saliva and time duration in the oral cavity, characteristics of the wire [dimensions, surface roughness] $\mathrm{pH}$ of saliva: The increase or decrease in the $\mathrm{pH}$ of the saliva has a direct correlation with the amount of nickel that leaches out of the wire. Theodore [2002], determined the amount of nickel and chromium released in artificial saliva at varying values of $\mathrm{pH} 5$ to 8 using atomic absorption 
spectrophotometer. Results showed that decrease on $\mathrm{pH}$ caused an increase in nickel \& chromium release levels. ${ }^{5}$ Time duration: Time duration affects the amount of nickel release, where the amount of nickel release is more at the initial hours and gradually decreases. Barrett \& Co-workers [1993], compared in vitro the corrosion rate of nickel and chromium from a standard orthodontic appliance consisting of bands, brackets and either stainless steel or nickel titanium arch wires. Samples were taken on days 1, 7, 14, 21 and 28 and were analysed using atomic absorption spectrophotometry. Their result indicated that the nickel release reaches a maximum after 1 week, then the rate of release diminishes over time. On the other hand, chromium release increases during the first 2 weeks and levels off during the subsequent 2 weeks. ${ }^{10}$ Characteristics of the wire [dimensions, surface roughness].

Dimension of the wire has a direct correlation as well, larger the dimension of the wire, the more amount of nickel leaches out. Increase in the amount of surface roughness, increases the amount of nickel release.

\section{Nickel Release in Various Commercially Available NiTi Wires - (Table 4)}

Nickel ion release differs for NiTi arch wires from different manufacturers. It differs with difference in surface characterization. Wires with a rough surface, release more nickel ion into the oral cavity than a smooth surface. Nickel ion release into the saliva could cause cytotoxicity or genotoxicity or mutagenic effects. So, different modifications were made in NiTi wires for reduction in nickel ion release. ${ }^{19}$ Ion implanted nickel-titanium arch wires form amorphous surface layer when bombarded with nitrogen ions. This layer gives corrosion resistance by replacing nickel ions.

Other type of alteration is by coating the arch wire with plastic or resin [like epoxy coated NiTi] or by adding $\mathrm{Cu}$ [CuNiTi]. CuNiTi arch wires show less release of nickel ion when compared to conventional NiTi wires, however still more than stainless steel arch wires. When used along with MIM brackets, epoxy coated NiTi and CuNiTi has less time dependent discharge of nickel ion. Nickel ion release from NiTi wire can be reduced by different means. On comparing the nickel ion release between conventional NiTi, copper NiTi and multi-stranded NiTi, conventional Niti released nickel the most in as received state and multi-stranded NiTi after oral stimulation. In both states, CuNiTi had the least nickel discharge. ${ }^{20}$ Though the quantity of nickel ion release is less than the toxic limit, it might cause allergic reaction in a sensitized population. In such cases, there are alternate options like TMA wires, twist flex stainless steel, fibrereinforced composite arch wires, pure titanium and goldplated arch wires. It is seen that nitinol wires with the thickest surface oxide $\mathrm{TiO} 2$ [up to $720 \mathrm{nM}$ ] showed the highest nickel release, which can be explained due to the presence of essentially pure nickel. ${ }^{1,3}$

\begin{tabular}{|c|c|c|c|c|c|c|c|c|}
\hline Sl. No. & $\begin{array}{l}\text { Author, Year, and } \\
\text { Location }\end{array}$ & $\begin{array}{l}\text { Type } \\
\text { of } \\
\text { Study }\end{array}$ & $\begin{array}{l}\text { Participants (n), } \\
\text { M / F (n), and } \\
\text { Age (Years) }\end{array}$ & $\begin{array}{c}\text { Source of Nickel } \\
\text { (bracket / arch } \\
\text { wire / ...) }\end{array}$ & $\begin{array}{l}\text { Characteristics of the } \\
\text { Attachment Used Such } \\
\text { as Slot/Dimension of the } \\
\text { Arch Wire etc }\end{array}$ & $\begin{array}{c}\text { Duration of } \\
\text { Time in the Oral } \\
\text { Cavity }\end{array}$ & Outcome & $\begin{array}{c}\text { Any Other } \\
\text { Details from the } \\
\text { Article That Can } \\
\text { be Recorded }\end{array}$ \\
\hline 1 & $\begin{array}{l}\text { Theodore Eliade's et al. } \\
\text { 2004, AO, Greece }\end{array}$ & In vivo & $\begin{array}{l}\text { 45, no sex prevalence, no } \\
\text { age range. } \\
45 \text { retrieved wires from } \\
\text { patients }\end{array}$ & $\begin{array}{l}\text { NiTi and arch } \\
\text { formed SS wires }\end{array}$ & $\begin{array}{l}\text { Pre formed arch wires, } 16 * 22 \\
\text { rectangular were ligated to } \\
0.018 \text { slot } \mathrm{SS} \text { brackets, by } \\
\text { means of ligature wires or } \\
\text { modules }\end{array}$ & 4 months & $\begin{array}{l}\text { No statistical } \\
\text { difference in the Ni } \\
\text { amount between } \\
\text { as received and } \\
\text { retrieved wires }\end{array}$ & $\begin{array}{c}\text { SEM was used to } \\
\text { Vi assess the elemental } \\
\text { composition of the } \\
\text { wire after intra oral } \\
\text { exposure }\end{array}$ \\
\hline 2 & $\begin{array}{l}\text { E. Espinar et al. 2011, } \\
\text { France }\end{array}$ & In vitro & 10 NiTi arch wires, & NiTi arch wire & Pre formed arch wires & $\begin{array}{c}\text { Wires were oxidised } \\
\text { to see if a } \\
\text { homogenous layer } \\
\text { was being formed }\end{array}$ & $\begin{array}{l}\mathrm{d} 20 \mathrm{~nm} \text { thick layer } \\
\text { was nickel free } \\
\text { after oxidisation }\end{array}$ & \\
\hline 3. & $\begin{array}{l}\text { Huma D, Sreedevi D, } \\
\text { Ajith; 2016; JOBCR; } \\
\text { India }\end{array}$ & In vitro & $\begin{array}{l}50 \text { simulated ortho } \\
\text { appliances, }\end{array}$ & Niti and SS arch wire & $\begin{array}{l}\text { Simulated ortho appliances, } \\
\text { half an arch, } 5 \text { groups. }\end{array}$ & 3 months & $\begin{array}{l}\text { Highest amount of } \\
\text { nickel was } \\
\text { released from NiTi } \\
\text { wires }\end{array}$ & \\
\hline 4. & $\begin{array}{l}\text { Barat, Farzaneh, } \\
\text { Berahman, Samaneh; } \\
\text { 2014, Iran }\end{array}$ & In vitro & $\begin{array}{l}\text { 120, } 40 \text { in each group. } \\
\text { single stranded NiTi, multi } \\
\text { stranded NiTi, copper NiTi }\end{array}$ & Arch wires & 0.016 round wires & $\begin{array}{l}2 \text { months in an } \\
\text { artificial salivary } \\
\text { environment }\end{array}$ & $\begin{array}{c}\text { Single stranded } \\
\text { NiTi released most } \\
\text { amount of } \mathrm{Ni}, \\
\text { followed by multi } \\
\text { stranded }\end{array}$ & $\begin{array}{l}\text { Cupper NiTi } \\
\text { released the least } \\
\text { amount of nickel }\end{array}$ \\
\hline 5. & $\begin{array}{l}\text { Visnja et al. 2017, } \\
\text { Croatia }\end{array}$ & In vitro & $\begin{array}{l}3 \text { pre formed arch wires, } \\
\text { artificial saliva }\end{array}$ & Arch wires & $\begin{array}{c}0.508 * 0.508 \mathrm{~mm} \text { arch wires, } \\
\text { NiTi with untreated surface, } \\
\text { rhodium coated NiTi and } \\
\text { nitride coated NTti }\end{array}$ & $\begin{array}{c}28 \text { days } \\
(3,7,14,21,28 \text { days })\end{array}$ & $\begin{array}{l}\mathrm{Ni} \text { ion release was } \\
\text { maximum from } \\
\text { NiTi with un } \\
\text { treated surface }\end{array}$ & $\begin{array}{l}\text { Hydrofluoric acid } \\
\text { concentration } \\
\text { predicts the release } \\
\text { of } \mathrm{Ni} \text { ions. }\end{array}$ \\
\hline 6. & $\begin{array}{l}\text { Vinoth kumar at al. } \\
\text { 2016, India }\end{array}$ & In vivo & $\begin{array}{c}10 \text { patients, } 14-23 \text { years } \\
\text { of age, }\end{array}$ & $\begin{array}{l}\text { Arch wires and FA } \\
\text { (SS brackets) }\end{array}$ & $\begin{array}{l}0.016 \text { NiTi wire, } 0.022 \text { slot } \\
\text { brackets }\end{array}$ & $\begin{array}{l}1 \text { month }(0,10 \mathrm{~d} \text { and } \\
1 \mathrm{~m})\end{array}$ & $\begin{array}{c}\text { Levels of Ni was } \\
\text { stat significant } \\
\text { d with a gradual } \\
\text { increase in } 10 \text { days } \\
\text { and a decrease } \\
\text { after }\end{array}$ & $\begin{array}{c}\text { Significant } \\
\text { Chromium levels } \\
\text { sere detected on } \\
\text { the } 30^{\text {th }} \text { day }\end{array}$ \\
\hline 7. & $\begin{array}{l}\text { Shabalovskaya et al. } \\
\text { 2008, Ireland }\end{array}$ & In vitro & 3 wires, Nitinol & $\begin{array}{l}0.075 \mathrm{~mm} \text { diameter } \\
\text { Nitinol wires }\end{array}$ & $\begin{array}{l}0.075 \mathrm{~mm} \text { diameter Nitinol } \\
\text { wires (wire } 1 \text { and } 2 \text { were } \\
\text { drawn using synthetic poly } \\
\text { crystalline diamond dies, wire } \\
3 \text { was drawn using single } \\
\text { crystal natural diamond }\end{array}$ & 5 months & $\begin{array}{l}\text { Significant levels of } \\
\text { nickel released } \\
\text { from all } 3 \text { wires }\end{array}$ & $\begin{array}{c}\text { Significant amount } \\
\text { of nickel was } \\
\text { released even if the } \\
\text { surface layers of } \\
\text { wires were adjusted }\end{array}$ \\
\hline 8 & $\begin{array}{l}\text { Arash Azizi et al. Iran, } \\
2016\end{array}$ & In vitro & $\begin{array}{l}40 \text { round wires and } 40 \\
\text { rectangular wires }\end{array}$ & Arch wires & $\begin{array}{c}0.020 \text {-inch round NiTi wire } \\
\text { and } 16^{*} 16^{\prime \prime} \text { rectangular NiTi } \\
\text { wire }\end{array}$ & $\begin{array}{l}21 \text { days in artificial } \\
\text { saliva }(1 \mathrm{~h}, 24 \mathrm{~h}, 1 \mathrm{w} \\
\text { and } 3 \mathrm{w})\end{array}$ & $\begin{array}{l}\text { Higher } \mathrm{Ni} \text { ion } \\
\text { release from } \\
\text { rectangular wires }\end{array}$ & \\
\hline 9 & $\begin{array}{l}\text { Barrett et al. USA, 1993, } \\
\text { AJODO }\end{array}$ & In vitro & 10 sets & $\begin{array}{l}\text { Brackets and arch } \\
\text { wires }\end{array}$ & $\begin{array}{c}17 * 25 \text { " rectangular NiTi wire } \\
(5 \text { nos) and SS wire used ( } 5 \\
\text { nos). }\end{array}$ & $\begin{array}{c}28 \text { days } \\
(1,7,14,21 \text { and } 28)\end{array}$ & $\begin{array}{c}\text { Significant } \\
\text { amounts of } \mathrm{Ni} \text { and } \\
\text { Cr were released in } \\
\text { the } 1^{\text {st }} \text { week. } \\
\text { Amount of } \mathrm{Ni} \\
\text { release was } 37 \\
\text { times greater than } \\
\text { that of } \mathrm{Cr}\end{array}$ & $\begin{array}{l}\text { d Increased amounts } \\
\text { of Cr were released } \\
\text { in the second week. }\end{array}$ \\
\hline
\end{tabular}




\begin{tabular}{|c|c|c|c|c|c|c|c|c|}
\hline Sl. No. & $\begin{array}{l}\text { Author, Year, } \\
\text { and Location }\end{array}$ & $\begin{array}{l}\text { Type of } \\
\text { Study }\end{array}$ & $\begin{array}{c}\text { Participants (n), } \\
\text { M / F (n), and Age } \\
\text { (Years) }\end{array}$ & $\begin{array}{c}\text { Source of Nickel } \\
\text { (bracket / arch } \\
\text { wire /) }\end{array}$ & $\begin{array}{l}\text { Characteristics of the } \\
\text { Attachment Used } \\
\text { Such as } \\
\text { Slot/Dimension of the } \\
\text { Arch Wire etc }\end{array}$ & $\begin{array}{l}\text { Duration of } \\
\text { Time in the Oral } \\
\text { Cavity }\end{array}$ & Outcome & $\begin{array}{c}\text { Any Other Details } \\
\text { from the Article } \\
\text { That Can be } \\
\text { Recorded }\end{array}$ \\
\hline 1 & $\begin{array}{l}\text { Gopikrishnan, Anil, } \\
\text { Ajith and Binoy; } \\
\text { 2014, India }\end{array}$ & In vitro & 4 wires & 4 arch wires, & $\begin{array}{l}17 * 25 \text { " SS, NiTi, TMA, } \\
\text { copper NiTi wires }\end{array}$ & $\begin{array}{l}28 \text { days in artificial } \\
\text { saliva }(7,14,21,28)\end{array}$ & $\begin{array}{l}\mathrm{Ni} \text { ion release along } \\
\text { with chromium and } \\
\text { iron from } \mathrm{SS}, \mathrm{CuNiTi} \\
\text { and } \mathrm{NiTi}\end{array}$ & $\begin{array}{l}\text { Least to none from } \\
\text { TMA }\end{array}$ \\
\hline 2 & $\begin{array}{l}\text { Huma, Sreedevi, } \\
\text { Prachi; 2016, India }\end{array}$ & In vitro & 50 samples & $\begin{array}{l}\text { Simulated FA, } \\
\text { and arch wires }\end{array}$ & $\begin{array}{c}4 \text { types of wires. A - } \\
\text { control } \\
\text { B\&C - SS wire } \\
\text { D\&E - NiTi and CuNiTi } \\
\text { resp } \\
16^{*} 22^{\prime \prime}\end{array}$ & $\begin{array}{l}3 \text { months (1 day, } 7 \\
\text { days, } 1 \mathrm{~m}, 2 \mathrm{~m} \text { and } 3 \\
\mathrm{~m})\end{array}$ & $\begin{array}{l}\mathrm{Ni} \text { ion release was } \\
\text { maximum at the end } \\
\text { of } 1^{\text {st }} \text { month. Non- } \\
\text { significant difference } \\
\text { at the end of } 3 \text { months }\end{array}$ & $\begin{array}{l}\text { More nickel release } \\
\text { from NiTi wires }\end{array}$ \\
\hline 3 & $\begin{array}{l}\text { Arash Azizi et al. } \\
\text { Iran, } 2016\end{array}$ & In vitro & $\begin{array}{l}40 \text { round wires and } \\
40 \text { rectangular wires }\end{array}$ & Arch wires & $\begin{array}{c}0.020 \text {-inch round NiTi wire } \\
\text { and } 16 * 16^{\prime \prime} \text { rectangular } \\
\text { NiTi wire }\end{array}$ & $\begin{array}{l}21 \text { days in artificial } \\
\text { saliva ( } 1 \mathrm{~h}, 24 \mathrm{~h}, 1 \mathrm{w} \\
\quad \text { and } 3 \mathrm{w})\end{array}$ & $\begin{array}{l}\text { Higher } \mathrm{Ni} \text { ion release } \\
\text { from rectangular } \\
\text { wires }\end{array}$ & \\
\hline 4 & $\begin{array}{l}\text { Rabindra S Nayak et } \\
\text { al. 2015, India }\end{array}$ & In vivo & $\begin{array}{l}30 \text { patients, saliva } \\
\text { sample was taken } \\
\text { prior and } 10-12 \\
\text { months after initial } \\
\text { arch wire placement, } \\
13-30 \text { years of age }\end{array}$ & $\begin{array}{c}0.022 \text { MBT SS } \\
\text { brackets and arch } \\
\text { wires }\end{array}$ & $\begin{array}{c}0.014,0.016 \mathrm{NiTi} \\
17 * 25,19 * 25 \mathrm{heat} \\
\text { activated NiTi, } 17 * 25 \\
19 * 25 \mathrm{NiTi}\end{array}$ & $10-12$ months & $\begin{array}{l}\text { Significant } \mathrm{Ni} \text { ion } \\
\text { concentration in the } \\
\text { saliva after initial } \\
\text { alignment }\end{array}$ & $\begin{array}{l}\text { Significant amounts } \\
\text { of chromium were } \\
\text { also detected }\end{array}$ \\
\hline 5 & $\begin{array}{l}\text { Mashallah et al. } \\
\text { 2016, Iran }\end{array}$ & In vivo & $\begin{array}{l}42 \text { patients, } 13-27 \\
\text { years of age }\end{array}$ & $\begin{array}{l}0.022 \text { MBT slot, SS } \\
\text { brackets and arch } \\
\text { wires }\end{array}$ & $\begin{array}{l}0.014 " \text { Niti, } 0.014 " \text { CuNiti } \\
\text { and 0.014" Epoxy Niti }\end{array}$ & 2 months & $\begin{array}{c}\text { High Ni ion } \\
\text { concentration in the } \\
\text { saliva in patients in } \\
\text { Grp A, and least in } \\
\text { Group C }\end{array}$ & \\
\hline 6 & $\begin{array}{l}\text { Huang et al. 2003, } \\
\text { Taiwan }\end{array}$ & In vitro & $\begin{array}{c}4 \text { wires were } \\
\text { immersed in artificial } \\
\text { saliva }\end{array}$ & $\begin{array}{l}\text { Preformed wires in } \\
\text { artificial saliva }\end{array}$ & $\begin{array}{l}0.016 \text { round Niti }- \text { Ormco, } \\
\text { RMO, KH and SY } \\
\text { companies }=4 \text { wires }\end{array}$ & $\begin{array}{c}28 \text { days } \\
(1,7,14,21,28)\end{array}$ & $\begin{array}{l}\text { All wires released } \\
\text { similar amounts of } \mathrm{Ni} \\
\text { ion, with a constant } \\
\text { increase over the time } \\
\text { period, but not } \\
\text { significant enough to } \\
\text { worry about. }\end{array}$ & \\
\hline
\end{tabular}

\begin{tabular}{|c|c|c|c|c|c|c|c|}
\hline $\begin{array}{l}\text { Sl. } \\
\text { No. }\end{array}$ & $\begin{array}{c}\text { Author, Year, and } \\
\text { Location }\end{array}$ & $\begin{array}{l}\text { Type of } \\
\text { Study }\end{array}$ & $\begin{array}{l}\text { Participants (n), } \\
\text { M / F (n), and } \\
\text { Age (Years) }\end{array}$ & $\begin{array}{c}\text { Source of } \\
\text { Nickel (bracket } \\
\text { / arch wire / } \\
\text {...) }\end{array}$ & $\begin{array}{l}\text { Characteristics of the } \\
\text { Attachment Used Such Duration of Time } \\
\text { as Slot/Dimension of the in the Oral Cavity } \\
\text { Arch Wire etc }\end{array}$ & Outcome & $\begin{array}{c}\text { Any Other } \\
\text { Details from } \\
\text { the Article } \\
\text { That Can be } \\
\text { Recorded }\end{array}$ \\
\hline 1 & $\begin{array}{c}\text { Camilla et al. 2016, } \\
\text { Brazil }\end{array}$ & In vivo & $\begin{array}{c}\text { 42, } 28 \text { females and } 14 \text { males, } \\
10-45 \text { years of age }\end{array}$ & $\begin{array}{l}\text { Conventional } \\
\text { braces and nickel } \\
\text { free braces }\end{array}$ & $\begin{array}{c}\text { Patients underwent FA Rx for } 12 \text { months }(0,3,6,9,12 \\
\begin{array}{c}12 \text { months; patch test was } \\
\text { done at regular intervals. } 1 \text { month after } \\
\text { removal of braces) }\end{array}\end{array}$ & $\begin{array}{l}\text { Patients treated with } \\
\text { nickel free braces, } \\
\text { had better gingival } \\
\text { health and smaller } \\
\text { blood changes }\end{array}$ & $\begin{array}{l}\text { All abnormalities } \\
\text { tended to be } \\
\text { eliminated after } \\
\text { removal of braces }\end{array}$ \\
\hline
\end{tabular}

\begin{tabular}{|c|c|c|c|c|c|c|c|c|c|c|c|c|c|c|}
\hline Articles & $\begin{array}{l}\text { Theodore } \\
\text { et al. } 5\end{array}$ & $\begin{array}{l}\text { E.Espinar } \\
\text { et al.14 }\end{array}$ & $\begin{array}{l}\text { Barat } \\
\text { et al. }\end{array}$ & $\begin{array}{l}\text { Visnja } \\
\text { et al. }{ }^{4}\end{array}$ & $\begin{array}{l}\text { Vinoth } S \\
\text { kumar } \\
\text { et al. }{ }^{7}\end{array}$ & $\begin{array}{c}\text { Shabalovskaya } \\
\text { et al. }{ }^{13}\end{array}$ & $\begin{array}{l}\text { Arash } \\
\text { Azizi } \\
\text { et al. }{ }^{3}\end{array}$ & $\begin{array}{l}\text { Barrett } \\
\text { et al.10 }\end{array}$ & $\begin{array}{c}\text { Gopi } \\
\text { Krishnan } \\
\text { et al.16 }\end{array}$ & $\begin{array}{l}\text { Huma } \\
\text { et al. }{ }^{12}\end{array}$ & $\begin{array}{c}\text { Rabindra } \\
\text { S Nayak } \\
\text { et al. }{ }^{1}\end{array}$ & $\begin{array}{l}\text { Mashallah } \\
\text { et al. }\end{array}$ & $\begin{array}{l}\text { Huang } \\
\text { et al. }{ }^{20}\end{array}$ & $\begin{array}{c}\text { Camila et } \\
\text { al.21 }\end{array}$ \\
\hline $\begin{array}{l}\text { Sample size } \\
\text { calculation }\end{array}$ & $\checkmark$ & $\checkmark$ & $x$ & $\checkmark$ & $\checkmark$ & $\checkmark$ & $\checkmark$ & $\checkmark$ & $\checkmark$ & $\checkmark$ & $\checkmark$ & $\checkmark$ & $\checkmark$ & $\checkmark$ \\
\hline $\begin{array}{l}\text { Representativeness of } \\
\text { orthodontic patients }\end{array}$ & $\checkmark$ & $x$ & $x$ & $x$ & $\checkmark$ & $x$ & $x$ & $x$ & $x$ & $x$ & $\checkmark$ & $\checkmark$ & $x$ & $\checkmark$ \\
\hline $\begin{array}{l}\text { Selection of the } \\
\text { orthodontic } \\
\text { control group }\end{array}$ & $x$ & $x$ & $x$ & $x$ & $x$ & $x$ & $x$ & $x$ & $x$ & $x$ & $\checkmark$ & $\checkmark$ & $x$ & $\checkmark$ \\
\hline $\begin{array}{l}\text { Assessment of nickel } \\
\text { release }\end{array}$ & $\checkmark$ & $\checkmark$ & $\checkmark$ & $\checkmark$ & $\checkmark$ & $\checkmark$ & $\checkmark$ & $\checkmark$ & $\checkmark$ & $\checkmark$ & $\checkmark$ & $\checkmark$ & $\checkmark$ & $x$ \\
\hline $\begin{array}{c}\text { Outcome of interest } \\
\text { not } \\
\text { present at the start }\end{array}$ & $\checkmark$ & $\checkmark$ & $\checkmark$ & $\checkmark$ & $\checkmark$ & $\checkmark$ & $x$ & $\checkmark$ & $\checkmark$ & $x$ & $\checkmark$ & $\checkmark$ & $\checkmark$ & $\checkmark$ \\
\hline $\begin{array}{l}\text { Assessors qualified to } \\
\text { provide results }\end{array}$ & $\checkmark$ & $\checkmark$ & $\checkmark$ & $\checkmark$ & $\checkmark$ & $\checkmark$ & $\checkmark$ & $\checkmark$ & $\checkmark$ & $\checkmark$ & $\checkmark$ & $\checkmark$ & $\checkmark$ & $\checkmark$ \\
\hline $\begin{array}{l}\text { Description of } \\
\text { inclusion / } \\
\text { exclusion criteria }\end{array}$ & $x$ & $x$ & $x$ & $x$ & $\checkmark$ & $x$ & $x$ & $x$ & $x$ & $x$ & $\checkmark$ & $\checkmark$ & $x$ & $\checkmark$ \\
\hline $\begin{array}{l}\text { Comparability of } \\
\text { groups on the } \\
\text { basis of the design }\end{array}$ & $\checkmark$ & $x$ & $\checkmark$ & $\checkmark$ & $\checkmark$ & $x$ & $x$ & $\checkmark$ & $\checkmark$ & $\checkmark$ & $\checkmark$ & $\checkmark$ & $\checkmark$ & $x$ \\
\hline $\begin{array}{c}\text { Assessment of factors } \\
\text { that could influence } \\
\text { outcome }\end{array}$ & $\checkmark$ & $\checkmark$ & $x$ & $\checkmark$ & $\checkmark$ & $x$ & $x$ & $\checkmark$ & $\checkmark$ & $\checkmark$ & $\checkmark$ & $\checkmark$ & $\checkmark$ & $\checkmark$ \\
\hline $\begin{array}{l}\text { Is the technique of } \\
\text { Assessment correct }\end{array}$ & $\checkmark$ & $\checkmark$ & $\checkmark$ & $\checkmark$ & $\checkmark$ & $\checkmark$ & $\checkmark$ & $\checkmark$ & $\checkmark$ & $\checkmark$ & $\checkmark$ & $\checkmark$ & $\checkmark$ & $\checkmark$ \\
\hline $\begin{array}{c}\text { Definitions and } \\
\text { assessment } \\
\text { of nickel release } \\
\text { clearly } \\
\text { reported }\end{array}$ & $\checkmark$ & $\checkmark$ & $\checkmark$ & $\checkmark$ & $\checkmark$ & $\checkmark$ & $\checkmark$ & $\checkmark$ & $\checkmark$ & $\checkmark$ & $\checkmark$ & $\checkmark$ & $\checkmark$ & $\checkmark$ \\
\hline $\begin{array}{c}\text { Adequacy of follow-up } \\
\text { of } \\
\text { patients }\end{array}$ & $x$ & $x$ & $x$ & $x$ & $\checkmark$ & $x$ & $x$ & $x$ & $x$ & $x$ & $\checkmark$ & $\checkmark$ & $x$ & $\checkmark$ \\
\hline $\begin{array}{l}\text { Validity of statistical } \\
\text { analysis }\end{array}$ & $\checkmark$ & $\checkmark$ & $x$ & $\checkmark$ & $\checkmark$ & $\checkmark$ & $\checkmark$ & $\checkmark$ & $\checkmark$ & $\checkmark$ & $\checkmark$ & $\checkmark$ & $\checkmark$ & $\checkmark$ \\
\hline Risk of bias & Low & Low & Low & Low & Low & Low & Low & Low & Low & Low & Low & Low & Low & Low \\
\hline \multicolumn{15}{|c|}{ Table 6. Bias Table Chart } \\
\hline
\end{tabular}


Studies comparing the amount of nickel release between, single stranded and multi stranded NTti wires manufactured by American Orthodontics, (Sheboygan, WI, USA), Ormco (Glendora, CA; Speed Supercable; Damon) showed that single stranded NiTi wires released more nickel comparatively. ${ }^{20}$

\section{Blood and Periodontal Evaluation after Orthodontic Treatment in Conventional and Nickel Free Brackets - (Table 5)}

Camilla et al. ${ }^{21}$ conducted a study where their objective was to evaluate prospectively gingival and blood status in patients allergic to nickel between two groups namely, conventional brackets and nickel free brackets. An analysis of white blood cells in allergic and non-allergic patients during and after treatment showed an increase in eosinophils, monocytes and basophils. They hypothesized that these results were not related to the removal of the appliances, but rather to the extensive exposure to nickel during treatment, as there was an increase in plasma nickel concentration in both groups.

The continuous low-level stimulus of antigens such as nickel raises the level of interleukin-4 (IL-4) produced by $\mathrm{T}$ cells, regardless of whether or not an individual is allergic, which favours a polarized immune response for a $T H 2$ profile, with a characteristic cell and molecule population through a pathway dependent on signal transducer and activator of transcription (STAT-6) and GATA-325. It was concluded that patients who were treated with nickel-free bracket have better gingival health and comparatively smaller blood changes than those treated with conventional method. All symptoms were eliminated after the removal of the brackets.

\section{DISCUSSION}

14 articles were selected from this systematic review. The corrosion resistance of different nickel titanium orthodontic products were different because of the variation in the percentage of composition. ${ }^{11}$ The corrosion resistance takes place in the form of ion release and it is assessed by immersing the orthodontic wires in artificial saliva at different time intervals. Regardless of the composition of metal alloys there will be corrosion taking place inside the oral environment and in some cases it can be exaggerated if there is any defect in the manufacturing process. ${ }^{12}$ More studies regarding the release of metals during treatment and changes in the composition of alloys have been done because of the simultaneous increase in the nickel hypersensitivity and demand for orthodontic treatment. A concept called the tolerance concept has been introduced in orthodontics for the cases of nickel hypersensitivity. According to this concept, people who are exposed to orthodontic appliances in their early stages of life will be less sensitive or tolerant to nickel when they are exposed in some other metal forms e.g., ear piercing. ${ }^{22} \mathrm{~A}$ study was conducted to assess the amount of DNA damage. When $1.18 \mu \mathrm{g}$ of nickel exposure has happened to human gingival fibroblast samples for 72 hours, mild damage has taken place which means that the amount of nickel concentration in orthodontic appliances is capable of producing cytotoxic effects. ${ }^{23}$ These results are in accordance with the study done by Fiorenzo Faccioni. ${ }^{24}$ The biocompatibility of orthodontic appliances (brackets, bands, wires) can be evaluated by determining the amount of metal ion release due to corrosion, both in vivo and iv vitro studies. In in vivo studies, the behaviour of the metals can be assessed but the collection of invasive samples (like blood) is difficult since it involves the patient consent. But the other samples such as saliva, urine can be collected and assessed. It should be made clear that the results that were obtained during the orthodontic treatment is only a momentary exposure and does not indicate lifetime or chronic exposure..$^{5-7}$

On the other hand, in vitro studies are performed in a laboratory-controlled environment but do not entirely mimic the conditions prevailing in the oral cavity. Orthodontic treatment, which includes the braces, influences the accumulation of biofilm and colonization of bacteria, thus making the patient more prone to inflammation and bleeding. Pazzini et al. found that nickel can influence inflammatory reactions throughout orthodontic treatment. Clinical features include gingival hyperplasia, changes in colour and gingival bleeding upon probing. ${ }^{25}$ Gursoy et al. ${ }^{26}$ in 2007 found that low-dose continuing nickel release from orthodontic appliances might be the initiating factor for gingival overgrowth, as it has the capability of increasing epithelial cell proliferation. Studies on the vascular changes in the periodontal ligament after removal of orthodontic forces showed that the pattern of blood vessel distribution in the periodontal ligament was likely to be affected by changes in the direction of tooth movement produced by the application and removal of the orthodontic force. Changes in the blood vessel number and density were associated with the direction of tooth movement. ${ }^{27}$ Even though orthodontic appliances do not have any direct effect on general health, it is enough to produce the changes in oral mucosa in minimal or non-toxic concentration. There are many studies done previously to show that the nickel components are capable of causing lung and nasal cancer. The mechanism underlying the genotoxic potential is unknown but several pathways have been explained such as the interaction of metal with DNA, causing oxidative DNA damage or the hindrance of DNA repair and replication process. The present study has recorded significant amount of nickel release from all groups of samples. Even though there have been several studies conducted regarding the effects of nickel on periodontium, no studies have been carried out to determine the amount of nickel release that will produce carcinogenic effect. The amount of nickel and chromium release from the appliances is much less than the dietary intake but it is sufficient to produce an allergic reaction in those who are sensitive to nickel. It also can produce important biological changes in oral mucosa. Thus, care should be taken.

\section{CONCLUSIONS}

Studies show that nickel leach out reaches a maximum after 7 days and eventually diminishes with time. Maximum nickel release was from brackets and bands combined. To conclude, this systematic review has shown that nickel solution at a minimal concentration could damage human gingival fibroblast and the nickel released from the different brands of the brackets were not uniform. Since the carcinogenic effect of nickel has been established it is high time to think about other biocompatible alloys without involving the heavy metal nickel 
which can be used, or to find standardization for the nickel to 'leach out' from the appliance. As much as we gain a large insight in this systematic review, there were a few limitations. More studies need to be conducted to deduce a further concise result.

\section{Future Scope}

There could be more studies conducted on the various types of NiTi wires that are constantly being introduced in the industry, and based on the updated literature, it will be easier for orthodontists to choose the right wire for a particular patient.

\author{
Abbreviations - \\ $\mathrm{Ni}$ Nickel \\ Cr Chromium \\ NiTi Nickel Titanium \\ DNA Deoxyribonucleic acid \\ TiO2 Titanium oxide \\ IL-4 Interleukin-4 \\ TH2 Helper T cells \\ STAT Signal Transducer and Activator of Transcription
}

Financial or other competing interests: None.

Disclosure forms provided by the authors are available with the full text of this article at jemds.com.

Author contributions: All authors contributed equally.

Data Availability - Available on request.

\section{REFERENCES}

[1] Nayak RS, Khanna B, Pasha A, et al. Evaluation of nickel and chromium ion release during fixed orthodontic treatment using inductively coupled plasma-mass spectrometer: an in vivo study. J Int Oral Health 2015;7(8):14-20.

[2] Park HY, Shearer TR. In vitro release of nickel and chromium from simulated orthodontic appliances. Am J Orthod 1983;84(2):156-9.

[3] Azizi A, Jamilian A, Nucci F, et al. Release of metal ions from round and rectangular NiTi wires. Prog Orthod 2016;17:10.

[4] Katic V, Curkovic L, Bosnjak MU, et al. Effect of $\mathrm{pH}$, fluoride and hydrofluoric acid conventration on ion release from $\mathrm{NiTi}$ wires with various coatings. Dent Mater J 2017;36(2):149-56.

[5] Eliades T, Athanasiou AE. In vivo aging of orthodontic alloys: implications for corrosion potential, nickel release and biocompatibility. Angle Orthod 2002;72(3):222-37.

[6] Deepa T, Thirrunavukkarasu N. Saliva as a potentioal diagnostic tool. Indian J Med Sci 2010;64(7):293-306.

[7] Kumar RV, Rajvikram N, Rajakumar P, et al. An accurate methodology to detect leaching of nickel and chromium in the initial phase of orthodontic treatment: an in vivo study. J Contemp Dent Pract 2016;17(3):205-10.

[8] Ramazanzadeh BA, Ahrari F, Sabzevari B, et al. Nickel ion release from 3 types of nickel titanium based orthodontic arch wires in the as-received state and after oral simulation. J Dent Res Dent Clin Dent Prospects 2014;8(2):71-6.

[9] Jaganathan N, Thiruvengadam C, Ramani P, et al. Salivary ferritin as a predictive marker of iron deficiency anemia in children. J Clin Pediatr Dent 2012;37(1):25-30.

[10] Barrett RD, Bishara SE, Quinn JK. Biodegradation of orthodontic appliances. Part 1. Biodegradation of nickel and chromium in vitro. Am J Orthod Dentofacial Orthop 1993;103(1):1-14.

[11] Kerosuo H, G Moe, E Kleven. In vitro release of nickel and chromium from different types of simulated orthodontic appliances. Angle Orthod 1995;65(2):111-6.

[12] Hussain HD, Ajith SD, Goel P. Nickel release from stainless steel and nickel titanium archwires-an in vitro study. J Oral Biol Craniofac Res 2016;6(3):213-8.

[13] Shabalovskaya SA, Tian H, Anderegg JW, et al. The influence of surface oxides on the distribution and release of nickel from nitinol wires. Biomaterials 2009;30(4):468-77.

[14] Espinar E, Llamas JM, Ginebra MP, et al. Reduction of Ni release and improvement of the friction behaviour of NiTi orthodontic archwires by oxidation treatments. J Mater Sci Mater Med 2011;22(5):1119-25.

[15] Castro SM, Ponces MJ, Lopes JD, et al. Orthodontic wires and its corrosion-the specific case of stainless steel and beta titanium. Journal of Dental Sciences 2015;10(1):1-7.

[16] Gopikrishnan S, Melath A, Ajith VV, et al. A comparative study of biodegradation of various orthodontic arch wires: an in vitro study. J Int Oral Health 2015;7(1):12-7.

[17] Insabralde NM, Poletti T, Conti AC, et al. Comparison of mechanical properties of beta titanium wires between levelled and unlevelled brackets: an in vitro study. Prog Orthod 2014;15(1):42.

[18] Chakravarthu S, Padmanabhan S, Chitharanjan AB. Allergy and orthodontics. J Orthod Sci 2012;1(4):83-7.

[19] Masjedi MK, Niknam O, Jahromi NH, et al. Effects of fixed orthodontic treatment using conventiona, copperincluded, and epoxy-coated nickel titanium archwires on salivary nickel levels: a double blind randomized clinical trial. Biol Trace Elem Res J 2016;174(1):27-31.

[20] Huang HH, Chiu YH, Lee TH, et al. Ion release from NiTi orthodontic wires in artificial saliva with various acidities. Biomaterials 2003;24(20):3585-92.

[21] Pazzini CA, Pereira LJ, Marques LS, et al. Nickel-free vs conventional braces for patients allergic to nickel: gingival and blood parameters during and after treatment. Am J Orthod 2016;150(6):1014-9.

[22] Mikulewicz M, Chojnacka K. Trace metal release from orthodontic appliances by in vivo studies: a systematic literature review. Biol Trace Elem Res 2010;137(2):12738.

[23] Naranjo AA, Triviño ML, Jaramillo A, et al. Changes in the subgingival microbiota and periodontal parameters before and 3 months after bracket placement. Am J Orthod Dentofacial Orthop 2006;130(3):275:e17-22.

[24] Faccioni F, Franceschetti P, Cerpelloni M, et al. In vivo study on metal release from fixed orthodontic appliances and DNA damage in oral mucosa cells. Am J Orthod Dentofacial Orthop 2003;124(6):687-93.

[25] Pazzini CA, Júnior GO, Marques LS, et al. Prevalence of nickel allergy and longitudinal evaluation of periodontal 
abnormalities in orthodontic allergic patients. Angle Orthod 2009;79(5):922-7.

[26] Gursoy UK, Sokucu O, Uitto VJ, et al. The role of nickel accumulation and epithelial cell proliferation in orthodontic treatment-induced gingival overgrowth. Eur J Orthod 2007;29(6):555-8.
[27] Murrell EF, Yen EH, Johnson RB. Vascular changes in the periodontal ligament after removal of orthodontic forces. Am J Orthod Dentofacial Orthop 1996;110(3):280-6. 